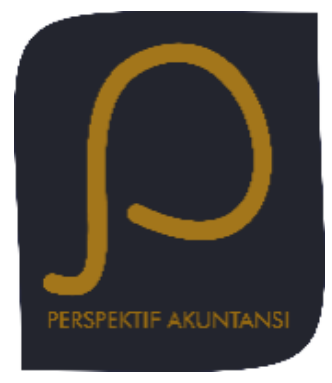

Perspektif Akuntansi

Volume 2 Nomor 3 (Oktober 2019), hal. 269-288

ISSN: 2623-0194 (Print), 2623-0186 (Online)

Copyright@ The Authors(s). All Rights Reserved

Fakultas Ekonomika dan Bisnis,

Universitas Kristen Satya Wacana

DOI: https://doi.org/10.24246/persi.vXiX.p269-288

http://ejournal.uksw.edu/persi

\title{
Pengaruh Pengungkapan Ekonomi, Lingkungan dan Sosial terhadap Nilai Perusahaan dengan Kinerja Keuangan Sebagai Variabel Antara
}

\author{
Rosa Linda Cahya Utami ${ }^{1}$ \\ Sekolah Tinggi Ilmu Ekonomi (STIE) Malangkuçeçwara Malang \\ Muslichah \\ Sekolah Tinggi Ilmu Ekonomi (STIE) Malangkuçeçwara Malang
}

\begin{abstract}
Received Abstract. The purpose of this paper is to analyze the mediating effects 10 Juni 2019 of economic, environmental, and social disclosures on the relationship between firm value and corporate financial performance. The Accepted population in this study is a banking sector company that is listed on 23 Juli 2019 the Indonesia stock exchange in the period 2013-2016, the sample was taken using a purposive sampling technique. The total sample used is eight banks. The results of this study prove that (1) economic disclosure does not affect the firm value. (2) environmental disclosure does not affect the firm value. (3) social disclosure affects the firm value. (4) economic disclosure influences financial performance. (5) environmental disclosure does not affect financial performance. (6) social disclosure influences financial performance. (7) financial performance affects the firm value. (8) economic disclosure indirectly affects the firm value through financial performance. (9) environmental disclosure does not affect the firm value through financial performance. (10) social disclosure indirectly affects the firm value through financial performance.
\end{abstract}

Keywords: Economic Disclosure, Environmental Disclosure, Social Disclosure, Financial Performance, Firm Value

Abtrak. Tujuan penelitian ini adalah untuk menganalisis pengaruh pemediasi pengungkapan ekonomi, lingkungan dan social pada hubungan antara nilai perusahaan dan kinerja keuangan korporat.

\footnotetext{
1 rosalindacahyautami97@yahoo.com
} 
Populasi penelitian ini adalah perusahaan di sektor perbankan yang terdaftar di Bursa Efek Indonesia periode 2013-2016, dengan sampel yang diperoleh dengan teknik purposive sampling. Sampel total yang digunakan adalah delapan bank. Hasil penelitian menunjukkan bahwa (1) pengungkapan ekonomi tidak mempengaruhi nilai perusahaan, (2) pengungkapan lingkungan tidak mempengaruhi nilai perusahaan, (3) pengungkapan sosial mempengaruhi nilai perusahaan, (4) pengungkapan ekonomi mempengaruhi kinerja keuangan, (5) pengungpakan lingkungan tidak mempengaruhi kinerja keuangan, (6) pengungkapan sosial mempengaruhi kinerja keuangan, (7) kinerja keuangan mempengarhuhi nilai perusahaan, (8) pengungkapan ekonomi secara tidak langsung mempengaruhi perusahaan melalui kinerja keuangan, (9) pengungkapan lingkungan tidak mempengarhi nilai perusahaan melalui kinerja keuangan, (10) pengungkapan sosial secara tidak langsung mempengaruhi nilai perusahaan melalui kinerja keuangan.

Kata kunci: Pengungkapan ekonomi, pengungkapan lingkungan, pengungkapan social, kinerja keuangan, nilai

\section{Pendahuluan}

Sebagian besar perusahaan yang terdapat di Indonesia hanya berfokus untuk mengungkapkan laporan keuangan. Padahal jika perusahaan memberikan informasi tambahan maka perusahaan dapat memberikan nilai lebih dan dapat menarik minat para investor untuk berinvestasi. Informasi tambahan dapat dituangkan oleh perusahaan dalam sustainability report. Sustainability report menjadi kebutuhan bagi perusahaan untuk menunjukkan pencapaian, proses, evaluasi dan agenda perusahaan dalam memaksimumkan dampak positif untuk mencapai tujuan pembangunan berkelanjutan yang berdasarkan pada keseimbangan pilar ekonomi, lingkungan dan social (GRI, 2006). Keberlanjutan atau sustainability adalah keseimbangan antara tiga aspek yaitu profit-ekonomi, planet-lingkungan dan people-sosial yang dikenal sebagai konsep triple bottom line (Gunawan dan Mayangsari, 2015). Kemudian, Puspitandari dan Septiani (2017) menyatakan bahwa selain mengejar profit, perusahaan harus memperhatikan dan ikut terlibat dalam pemenuhan kesejahteraan masyarakat (people), serta turut berkontribusi aktif dalam menjaga kelestarian lingkungan (planet).

Kegiatan yang dilakukan perusahaan tidak hanya dilaporkan kepada shareholder tetapi juga dilaporkan kepada stakeholder. Stakeholder adalah orang atau kelompok yang terpengaruh oleh dan atau bisa mempengaruhi operasi perusahaan dalam mencapai tujuannya (Karyawati, Yuniarta, \& Sujana, 2017). Stakeholder perusahaan terdiri atas berbagai pihak seperti manajer, pelanggan, pemasok, pesaing, pemerintah, karyawan, dan masyarakat umum. Pemegang saham menginginkan agar investasi yang ditanamkannya 
berkembang, pemerintah menginginkan agar perusahaan mengikuti aturan yang berlaku. Selanjutnya, masyarakat menginginkan agar perusahaan peduli terhadap kesejahteraan masyarakat di lingkungan sekitarnya dan perusahaan ingin berorientasi untuk mencari keuntungan ekonomi serta mampu melakukan proses produksi yang ramah lingkungan.

Perusahaan yang mengungkapkan sustainability report memiliki peluang yang besar untuk mendapatkan reputasi yang baik dikalangan masyarakat sehingga berdampak pada peningkatan kepercayaan masyarakat. Dengan mengungkapkan sustainability report perusahaan dapat terlihat lebih peduli terhadap stakeholder perusahaan. Hal tersebut dapat mempengaruhi pandangan stakeholder terhadap perusahaan yang dapat berdampak pada peningkatan manfaat ekonomi perusahaan serta meningkatkan nilai perusahaan.

Penelitian tentang hubungan pengungkapan ekonomi, lingkungan dan sosial terhadap kinerja keuangan dilakukan oleh Tarigan dan Semuel (2014) yang membuktikan bahwa pengungkapan ekonomi tidak berpengaruh terhadap kinerja keuangan, namun pengungkapan lingkungan dan sosial berpengaruh terhadap kinerja keuangan. Hutagalung dan Harahap (2016) membuktikan bahwa pengungkapan ekonomi dan lingkungan juga tidak berpengaruh terhadap kinerja keuangan, namun pengungkapan sosial berpengaruh terhadap kinerja keuangan.

Penelitian mengenai hubungan sustainability report terhadap nilai perusahaan yang dilakukan oleh Gunawan \& Mayangsari (2015) membuktikan bahwa sustainability report tidak berpengaruh terhadap nilai perusahaan. Penelitian mengenai sustainability report terhadap kinerja keuangan dan nilai perusahaan dilakukan oleh Safitri (2015) yang membuktikan bahwa pengungkapan sustainability report berpengaruh terhadap kinerja keuangan dan nilai perusahaan, Muallifin dan Priyadi (2016) membuktikan bahwa pengungkapan sustainability report tidak berpengaruh terhadap kinerja keuangan dan nilai perusahaan. Penelitian mengenai pengungkapan ekonomi, lingkungan, dan sosial terhadap kinerja keuangan dan nilai perusahaan dilakukan oleh Sejati \& Prastiwi (2015) yang membuktikan bahwa pengungkapan ekonomi, lingkungan dan sosial tidak berpengaruh terhadap kinerja keuangan dan nilai perusahaan.

Berdasarkan hasil penelitian yang telah dilakukan sebelumnya terdapat beberapa argumen untuk melakukan penelitian ini. Pertama, masih sedikit penelitian yang melakukan penelitian tentang pengungkapan ekonomi, lingkungan dan sosial secara terpisah. Kedua, penelitian mengenai pengaruh pengungkapan ekonomi, lingkungan dan sosial terhadap kinerja keuangan 
memberikan hasil yang berbeda. Karyawati, dkk (2017) menyatakan bahwa pengungkapan ekonomi, lingkungan dan sosial tidak berpengaruh terhadap kinerja keuangan. Sedangkan Tarigan dan Semuel (2014) menyatakan bahwa pengungkapan lingkungan dan sosial berpengaruh terhadap kinerja keuangan.

Hasil tersebut berbeda dengan Hutagalung \& Harahap (2016) yang menyatakan hanya pengungkapan sosial yang berpengaruh terhadap kinerja keuangan. Ketiga, belum banyak penelitian yang menggabungkan pengungkapan ekonomi, lingkungan dan sosial terhadap kinerja keuangan dan nilai perusahaan serta beberapa penelitian yang telah dilakukan memberikan hasil yang tidak konsisten. Seperti, Safitri (2015) yang menyatakan bahwa sustainability report berpengaruh terhadap kinerja keuangan dan nilai perusahaan. Sedangkan Sejati dan Prastiwi (2015), Muallifin dan Priyadi (2016) menyatakan bahwa sustainability report tidak berpengaruh terhadap kinerja keuangan dan nilai perusahaan. Dari ketiga alasan tersebut penulis tertarik ingin melakukan penelitian tentang pengungkapan ekonomi, lingkungan dan sosial secara terpisah serta menggabungkannya terhadap kinerja keuangan dan nilai perusahaan.

Berdasarkan argumen di atas maka tujuan penelitian ini adalah (1) menganalisis pengaruh pengungkapan ekonomi, lingkungan, dan sosial terhadap nilai perusahaan dan kinerja keuangan, (2) menganalisi pengaruh pengungkapan ekonomi, lingkungan, dan sosial terhadap nilai perusahaan dengan kinerja kinerja keuangan sebagai variabel mediasi. Penelitian ini menggunakan kinerja keuangan sebagai variabel mediasi dikarenakan terdapat beberapa penelitian terdahulu yang menggunakan kinerja keuangan sebagai variabel mediasi. Seperti penelitian yang dilakukan oleh Febri dan Ikbal (2018), Lutfia dan Sugiharti (2017), serta kinerja keuangan yang baik dapat memicu nilai perusahaan meningkat karena para investor cenderung untuk berinvestasi pada perusahaan yang memiliki kinerja keuangan yang baik.

\section{Telaah Pustaka}

\section{Stakeholder Theory}

Stakeholder theory menjelaskan kepada siapa saja perusahaan harus bertanggung jawab. Perusahaan tidak hanya bertanggung jawab kepada shareholder melainkan juga harus bertanggung jawab kepada stakeholder. Stakeholder adalah orang atau kelompok yang terpengaruh oleh dan atau bisa mempengaruhi operasi perusahaan dalam mencapai tujuannya (Karyawati, dkk, 2017). Perusahaan harus menjaga hubungan baik dengan stakeholder, salah satu strategi yang dilakukan perusahaan adalah dengan menerbitkan sustainability report yang memberikan informasi seputar ekonomi, lingkungan 
dan sosial perusahaan. Muallifin dan Priyadi (2016) menyatakan bahwa stakeholder theory menjelaskan mengenai pentingnya perusahaan untuk memenuhi keinginan stakeholder. Pengungkapan sustainability report dapat memenuhi keinginan stakeholder yang dapat menghasilkan keadaan yang harmonis antara perusahaan dengan stakeholder sehingga dapat mencapai keberlanjutan dan kelestarian perusahaan.

\section{Legitimacy Theory}

Legitimacy theory berfokus pada interaksi antara perusahaan dengan masyarakat. Legitimacy theory menjadi landasan bagi perusahaan untuk memperhatikan apa yang menjadi harapan masyarakat dan mampu menyelaraskan dengan norma sosial yang berlaku tempat perusahaan tersebut beroperasi (Muallifin dan Priyadi, 2016). Teori ini mendorong perusahaan untuk meyakinkan bahwa aktivitas dan kinerjanya dapat diterima oleh masyarakat. Laporan aktivitas pertanggungjawaban lingkungan dan sosial yang diungkapkan dalam sustainability report dapat digunakan oleh perusahaan untuk membuktikan bahwa perusahaan telah melaksanakan tanggungjawabnya. Hal tersebut merupakan upaya agar keberadaan dan aktivitas perusahaan dapat diterima atau dapat dikatakan terlegitimasi oleh masyarakat.

\section{Signalling Theory}

Signaling theory membahas mengenai dorongan perusahaan untuk mengungkapkan informasi kepada pihak eksternal. Informasi yang dikeluarkan oleh perusahaan merupakan hal yang penting, karena dapat mempengaruhi keputusan investasi pada pihak diluar perusahaan (Connelly, Certo, Ireland, \& Reutzel, 2011). Perusahaan yang melaporkan informasi seputar lingkungan dan sosial diharapkan dapat meningkatkan kinerja keuangan dan nilai perusahaan.

\section{Sustainability Report}

Sustainability report merupakan laporan yang memuat tidak saja informasi kinerja keuangan, tetapi juga informasi non-keuangan yang terdiri dari informasi aktivitas lingkungan dan sosial yang memungkinkan perusahaan bisa tumbuh secara berkesinambungan. Sustainability report menjadi kebutuhan bagi perusahaan untuk menunjukkan pencapaian, proses, evaluasi dan agenda perusahaan dalam memaksimumkan dampak positif untuk mencapai tujuan pembangunan berkelanjutan yang berdasarkan pada keseimbangan pilar ekonomi, lingkungan dan social (GRI, 2006).

Keberlanjutan atau sustainability adalah keseimbangan antara tiga aspek yaitu profit-ekonomi, planet-lingkungan dan people-sosial yang dikenal sebagai 
konsep triple bottom line (Gunawan \& Mayangsari, 2015). Pedoman yang dapat digunakan dalam pelaporan sustainability report adalah Global Reporting Initiative (GRI). Dalam GRI G-4 dijelaskan dua jenis pengungkapan standar yaitu standar umum dan khusus. Standar khusus dibagi menjadi tiga aspek yaitu aspek ekonomi, lingkungan dan sosial.

\section{Kinerja Keuangan}

Sulastri (2018) menyatakan bahwa kinerja keuangan adalah prestasi yang dicapai oleh perusahaan pada saat tertentu dengan menggunakan perhitungan berdasarkan tolak ukur analisis rasio yang didasarkan pada laporan keuangan. Laporan keuangan merupakan data yang dibutuhkan untuk menilai kinerja keuangan perusahaan dan umumnya penilaian kinerja keuangan perusahaan yang digunakan adalah analisis rasio keuangan. Berdasarkan laporan keuangan perusahaan yang telah diterbitkan tersebut dapat dihitung sejumlah rasio keuangan yang mencerminkan dari kinerja keuangan perusahaan. Salah satunya adalah rasio Return on Assets (ROA). ROA adalah rasio yang mengukur kemampuan perusahaan menghasilkan laba dengan menggunakan total aset (kekayaan) yang dimiliki bank setelah di sesuaikan dengan biaya-biaya yang digunakan untuk mendanai aset tersebut (Subandi \& Ghozali, 2013).

\section{Nilai Perusahaan}

Nilai perusahaan adalah suatu kondisi tertentu yang telah dicapai oleh suatu perusahaan yang tercermin dalam harga pasar saham perusahaan (Rahayu \& Sari, 2018). Nilai perusahaan dapat diukur dengan menggunakan rasio harga saham yang disebut dengan rasio penilaian. Salah satunya adalah rasio Tobins' $Q$. Tobins' $Q$ adalah nilai pasar dari suatu perusahaan dengan membandingkan nilai pasar perusahaan yang terdaftar di pasar keuangan dengan nilai buku total aset perusahaan (Muallifin \& Priyadi, 2016). Rasio ini lebih unggul daripada rasio yang lain, karena rasio ini berfokus pada berapa nilai perusahaan saat ini secara relatif terhadap berapa biaya yang dibutuhkan untuk menggantinya saat ini. Tobins ' $Q$ merupakan ukuran yang lebih teliti mengenai keefektifan manajemen memanfaatkan sumber-sumber daya ekonomis dalam kekuasaannya.

\section{Pengembangan Hipotesis}

\section{Pengaruh Pengungkapan Ekonomi, Lingkungan, dan Sosial Terhadap Nilai Perusahaan}

Semakin terpenuhinya indeks dalam pengungkapan ekonomi, lingkungan dan sosial maka perusahaan dianggap telah melaksanakan dan bertanggung jawab atas kegiatan yang telah dilaksanakan perusahaan. Kondisi tersebut menjadi 
perhatian bagi stakeholder karena perusahaan dianggap peduli serta memenuhi tuntutan pertanggungjawaban bagi stakeholder. Apabila kepercayaan stakeholder terhadap perusahaan sudah terbangun, maka perusahaan akan mendapatkan legitimasi.

Perusahaan dianggap mampu untuk memenuhi harapan serta mampu menyelaraskan dengan norma sosial di tempat perusahaan beroperasi. Untuk mendapatkan legitimasi dari masyarakat perusahaan perlu untuk mengungkapkan informasi terkait ekonomi, lingkungan dan sosial. Informasi yang diungkapkan oleh perusahaan merupakan sinyal kepada stakeholder untuk memperoleh dukungan agar membantu keberlanjutan perusahaan. Informasi yang diterima dapat mempengaruhi pengambilan keputusan untuk berinvestasi. Keputusan investasi dapat berupa permintaan terhadap pembelian saham perusahaan yang diharapkan dapat meningkatkan harga saham sekaligus meningkatkan nilai perusahaan.

Hal tersebut telah dibuktikan dalam penelitian yang dilakukan oleh Safitri (2015), Kusuma dan Priantinah (2018) yang membuktikan bahwa sustainability report berpengaruh terhadap nilai perusahaan. Berdasarkan penjelasan tersebut dapat dirumuskan hipotesis sebagai berikut:

$\mathrm{H}_{1 \mathrm{a}}$ : Pengungkapan ekonomi berpengaruh terhadap nilai perusahaan.

$\mathrm{H}_{1 \mathrm{~b}}$ : Pengungkapan lingkungan berpengaruh terhadap nilai perusahaan.

$\mathrm{H}_{1 c}$ : Pengungkapan sosial berpengaruh terhadap nilai perusahaan.

Pengaruh Pengungkapan Ekonomi, Lingkungan, dan Sosial Terhadap Kinerja Keuangan

Perusahaan harus menjaga hubungan baik dengan stakeholder. Salah satu strategi yang dapat digunakan adalah dengan menerbitkan sustainability report yang memberikan informasi seputar ekonomi, lingkungan dan sosial. Sustainability report dapat digunakan untuk menjawab tuntutan dari para stakeholder. Stakeholder dapat mengetahui kinerja perusahaan yang peduli akan lingkungan dan sosial dan dapat memberikan respon positif dengan memberikan pendanaan bagi perusahaan.

Pendanaan dapat berupa investasi dengan membeli saham dari perusahaan. Hasil dari pendanaan tersebut yang nantinya akan digunakan untuk meningkatkan operasional perusahaan yang dapat meningkatkan profitabilitas perusahaan. Profitabilitas yang semakin meningkat dapat meningkatkan kinerja keuangan perusahaan.

Hal tersebut telah dibuktikan dalam penelitian yang dilakukan oleh Hutagalung dan Harahap (2016) yang membuktikan bahwa pengungkapan sosial 
berpengaruh terhadap kinerja keuangan, Tarigan \& Semuel (2014) membuktikan bahwa pengungkapan lingkungan dan sosial berpengaruh terhadap kinerja keuangan, Safitri, (2015), Muallifin dan Priyadi (2016) dan Puspitandari dan Septiani (2017) membuktikan bahwa sustainability report berpengaruh terhadap kinerja keuangan. Berdasarkan penjelasan tersebut dapat dirumuskan hipotesis sebagai berikut:

$\mathrm{H}_{2 \mathrm{a}}$ : Pengungkapan ekonomi berpengaruh terhadap kinerja keuangan.

$\mathrm{H}_{2 \mathrm{~b}}$ : Pengungkapan lingkungan berpengaruh terhadap kinerja keuangan.

$\mathrm{H}_{2 c}$ : Pengungkapan sosial berpengaruh terhadap kinerja keuangan.

\section{Pengaruh Kinerja Keuangan Terhadap Nilai Perusahaan}

Kinerja keuangan perusahaan tercermin dalam laporan keuangan perusahaan. Laporan keuangan merupakan sumber dari berbagai macam informasi bagi investor dan sebagai salah satu pertimbangan dalam pengambilan keputusan untuk investasi. Untuk menjaga kelangsungan perusahaan, perusahaan harus dalam kondisi yang menguntungkan. Kondisi tanpa keuntungan akan sulit bagi perusahaan untuk dapat menarik modal dari luar. Dalam rangka menarik minat investor, perusahaan harus mampu lebih efisien dan menguntungkan serta memiliki prospek pertumbuhan yang baik. ROA menggambarkan kinerja keuangan perusahaan dalam menghasilkan laba bersih dan aktiva yang digunakan untuk operasional perusahaan. ROA yang semakin tinggi menunjukkan bahwa kinerja keuangan perusahaan semakin baik, sehingga akan meningkatkan image perusahaan yang pada akhirnya akan meningkatkan pula nilai perusahaan.

Jika laba yang diperoleh perusahaan terus meningkat, maka dapat memberikan gambaran bahwa perusahaan memiliki kinerja yang baik dan mampu memberikan pengembalian atas investasi yang dilakukan investor. Investor tidak akan ragu untuk berinvestasi pada perusahaan yang memiliki kinerja yang baik, karena investor percaya jika perusahaan akan mampu untuk mengembalikan investasi yang telah ditanamkannya. Semakin banyak investor yang membeli saham perusahaan maka harga saham akan meningkat yang kemudian dapat meningkatkan nilai perusahaan. Hal tersebut dapat diperkuat dengan adanya penelitian yang dilakukan oleh Gultom, dkk (2013), Ulum (2015), Sabrin, dkk (2016), Cheryta, dkk (2017) yang membuktikan bahwa profitabilitas berpengaruh terhadap nilai perusahaan. Berdasarkan penjelasan tersebut dapat dirumuskan hipotesis sebagai berikut:

$\mathrm{H}_{3}$ : Kinerja keuangan berpengaruh terhadap nilai perusahaan. 
Pengaruh Pengungkapan Ekonomi, Lingkungan, dan Sosial Terhadap Nilai Perusahaan Melalui Kinerja Keuangan

Pengungkapan ekonomi, lingkungan dan sosial yang diterbitkan perusahaan digunakan untuk menginformasikan kegiatan-kegiatan yang dilakukan perusahaan baik mengenai kinerja keuangan maupun kinerja non-keuangan. Informasi yang dikeluarkan oleh perusahaan merupakan hal yang penting guna mempengaruhi keputusan investasi pada pihak diluar perusahaan. Semakin terpenuhinya indeks dalam pengungkapan ekonomi, lingkungan dan sosial, maka perusahaan dianggap telah melaksanakan dan bertanggung jawab atas kegiatan yang telah dilaksanakan perusahaan. Kondisi tersebut merupakan pembuktian perusahaan kepada stakeholder bahwa perusahaan telah memperhatikan dan memenuhi apa yang menjadi harapan stakeholder dan mampu menyelaraskan dengan norma sosial ketika perusahaan beroperasi.

Dari pengungkapan ekonomi, lingkungan dan sosial, perusahaan mengharapkan adanya respon positif dengan memberikan pendanaan bagi perusahaan. Pendanaan dapat berupa investasi dengan membeli saham dari perusahaan. Hasil dari pendanaan tersebut yang nantinya akan digunakan untuk meningkatkan operasional perusahaan yang dapat meningkatkan profitabilitas perusahaan. Profitabilitas yang semakin meningkat dapat meningkatkan kinerja keuangan perusahaan. Investor tidak akan ragu untuk berinvestasi pada perusahaan yang memiliki kinerja keuangan yang baik, karena investor percaya jika perusahaan akan mampu untuk mengembalikan investasi yang telah ditanamkannya. Semakin banyak investor yang membeli saham perusahaan maka harga saham akan meningkat yang kemudian dapat meningkatkan nilai perusahaan Dari penjelasan tersebut dapat disimpulkan bahwa kinerja keuangan dapat memediasi pengungkapan ekonomi, lingkungan, dan sosial terhadap nilai perusahaan. Berdasarkan penjelasan tersebut dapat dirumuskan hipotesis sebagai berikut:

$\mathrm{H}_{4 \mathrm{a}}$ : Pengungkapan ekonomi berpengaruh terhadap nilai perusahaan melalui kinerja keuangan.

$\mathrm{H}_{4 \mathrm{~b}}$ : Pengungkapan lingkungan berpengaruh terhadap nilai perusahaan melalui kinerja keuangan.

$\mathrm{H}_{4 \mathrm{c}}$ : Pengungkapan sosial berpengaruh terhadap nilai perusahaan melalui kinerja keuangan.

\section{Model Penelitian}

Berdasarkan argumen pengembangan hipotesis di atas, maka model penelitian ini dapat digambarkan sebagai berikut: 


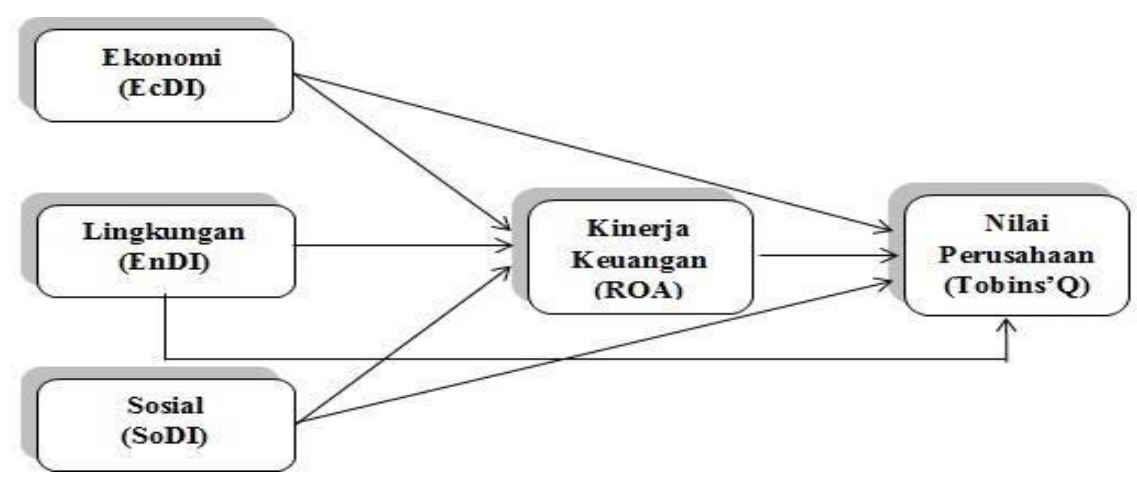

Gambar 1. Model Penelitian

\section{Metoda}

\section{Jenis Penelitian}

Jenis penelitian ini adalah penelitian kausalitas dengan pendekatan kuantitatif.

\section{Populasi dan Sampel}

Populasi penelitian yang digunakan adalah perusahaan sektor perbankan yang terdaftar di Bursa Efek Indonesia. Alasan menggunakan perusahaan sektor perbankan didasarkan pada argumen bahwa perusahaan sektor perbankan sebagai entitas bisnis yang menyediakan berbagai kebutuhan keuangan dalam bentuk jasa perbankan, juga memiliki dampak ekonomi dan sosial yang sangat erat. Walaupun dampak terhadap lingkungan bukan menjadi perhatian utama, namun jika melihat operasionalnya secara tidak langsung perusahaan juga berhubungan dengan lingkungan sekitarnya, karena perusahaan beroperasi ditengah lingkungan serta berkaitan dengan masyarakat. Pemilihan sampel menggunakan teknik purposive sampling. Berikut adalah proses pengambilan sampel dengan menggunakan teknik purposive sampling.

Tabel 1. Kriteria Sampel

\begin{tabular}{lc}
\hline \multicolumn{1}{c}{ Keterangan } & Jumlah \\
\hline Perusahaan sektor perbankan yang terdaftar di BEI & 42 \\
Perusahaan sektor perbankan yang menerbitkan laporan tahunan tahun & 42 \\
$2013-2016$ & 8 \\
$\begin{array}{l}\text { Perusahaan sektor perbankan yang menerbitkan sustainability report } \\
\text { tahun 2013-2016 }\end{array}$ & 8 \\
Tahun pengamatan & 4 \\
\hline Jumlah & 32 \\
\hline
\end{tabular}




\section{Definisi Operasional dan Pengukuran}

\section{Variabel Independen}

Variabel independen yang digunakan adalah pengungkapan ekonomi, lingkungan dan sosial.

1. Pengungkapan Ekonomi

Menurut GRI G-4 dimensi keberlanjutan ekonomi adalah pengungkapan yang berkaitan dengan dampak perusahaan terhadap keadaan ekonomi bagi stakeholder perusahaan dan terhadap sistem ekonomi di tingkat lokal, nasional, dan global. Pengungkapan ekonomi diukur melalui Economic Disclosure Index (EcDI). Aspek ekonomi dalam pedoman GRI G-4 terdapat 9 pokok. Rumus perhitungan EcDI adalah:

$\mathrm{EcDI}=\frac{\mathbf{K}}{\mathbf{N}}$

2. Pengungkapan Lingkungan

Menurut GRI G-4 dimensi keberlanjutan lingkungan adalah pengungkapan yang berkaitan dengan dampak perusahaan pada sistem alam yang hidup dan tidak hidup, termasuk tanah, udara, air, dan ekosistem. Pengungkapan lingkungan diukur melalui Environmental Disclosure Index (EnDI).

Aspek lingkungan dalam pedoman GRIG-4 terdapat 34 pokok. Rumus perhitungan EnDI adalah:

$$
\operatorname{EnDI}=\frac{\mathbf{K}}{\mathbf{N}}
$$

\section{Pengungkapan Sosial}

Menurut GRI G-4 dimensi keberlanjutan sosial adalah pengungkapan yang membahas dampak yang dimiliki perusahaan terhadap sistem sosial ketika perusahaan beroperasi. Pengungkapan sosial diukur melalui Social Dislosure Index (SoDI). Aspek sosial dalam pedoman GRIG-4 terdapat 48 pokok.

Rumus perhitungan SoDI adalah:

SoDI $=\frac{\mathbf{K}}{\mathbf{N}}$

\section{Variabel Dependen}

Variabel dependen yang digunakan adalah nilai perusahaan. Nilai perusahaan adalah suatu kondisi tertentu yang telah dicapai oleh perusahaan yang tercermin dalam harga pasar saham perusahaan (Rahayu dan Sari, 2018). Nilai perusahaan diukur menggunakan skala pengukuran rasio Tobin's Q. Tobin's $Q$ merupakan rasio yang digunakan untuk mengetahui besaran nilai pasar 
perusahaan terhadap nilai buku total asset (Muallifin dan Priyadi, 2016). Tobin's Q tidak hanya memberikan gambaran pada aspek fundamental tetapi sejauh mana pasar menilai perusahaan dari berbagai aspek yang dilihat oleh pihak luar termasuk investor (Safitri, 2015). Tobin's Q dihitung menggunakan rumus sebagai berikut:

$\mathrm{Q}=\frac{(\text { TAt-BVE })+\text { MVE })}{\text { TAt }}$

\section{Variabel Antara}

Variabel antara yang digunakan adalah kinerja keuangan. Sulastri (2018) menyatakan bahwa kinerja keuangan adalah prestasi yang dicapai oleh perusahaan pada saat tertentu dengan menggunakan perhitungan berdasarkan tolak ukur analisis rasio yang didasarkan pada laporan keungan.Kinerja keuangan yang digunakan adalah rasio profitabilitas. Rasio profitabilitas bertujuan untuk mengukur kemampuan perusahaan dalam memperoleh laba, baik dalam hubungannya dengan penjualan, aset, maupun terhadap modal sendiri (Muallifin dan Priyadi, 2016). Salah satu rasio yang dapat digunakan adalah ROA. ROA merupakan rasio terpenting diantara rasio profitabilitas, dan merupakan teknik analisis yang lazim digunakan untuk mengukur tingkat efektivitas dari keseluruhan operasi perusahaan (Safitri, 2015). ROA dihitung menggunakan rumus sebagai berikut:

Return on Asset $(\mathrm{ROA})=\frac{\text { Laba Bersih Setelah pajak }}{\text { Total Aset }}$

\section{Metode Analisis}

Metode analisis data yang digunakan adalah Partial Least Square (PLS) yang menggunakan software SmartPLS 3.0. Menurut Wold (1985) dalam Ghozali (2008) PLS merupakan metode analisis yang kuat karena tidak didasarkan dengan banyak asumsi. Pendekatan PLS adalah distribution free yaitu tidak mengasumsikan data berdistribusi tertentu, dapat berupa nominal, kategori, ordinal, interval dan rasio (Ghozali, 2008).

Bagian ini menjelaskan secara eksplisit bagaimana penelitian dilakukan. Metode penelitian merupakan prosedur dan teknik penelitian. Bagian ini harus diatur secara efektif agar pembaca dapat memperoleh gambaran yang lengkap mengenai materi, alat analisis, dan tahapan yang diterapkan untuk menjawab pertanyaan penelitian. Berikut ini contoh sub-bagian atau sub-heading dalam bagian Metoda. 


\section{Hasil dan Pembahasan}

\section{Hasil}

Gambar 2 menyajikan hasil penelitian. Hasil penelitian ini dilanjutkan dengan pembahasan untuk masing-masing hipotesis.

\section{H1a: Pengungkapan Ekonomi Berpengaruh Terhadap Nilai Perusahaan}

Path coefficient menunjukkan bahwa hubungan antara pengungkapan ekonomi dengan nilai perusahaan tidak berpengaruh dengan nilai T-Statistic sebesar $1.891<$ T-Table sebesar 2.056 dan P-Value sebesar $0.059>0,05(\alpha=5 \%)$. Nilai dari original sampel $-0,276$. Hipotesis $\mathrm{H} 1$ a dalam penelitian ini ditolak. Hal ini mengindikasi bahwa harga dari jumlah saham yang beredar di bursa maupun akun lainnya yang bersangkutan tidak terpengaruh oleh pengungkapan ekonomi perusahaan (Sejati dan Prastiwi, 2015). Dalam pengambilan keputusan untuk berinvestasi, seorang investor cukup dengan melihat informasi dalam laporan keuangan. Laporan keuangan dianggap cukup untuk mewakili informasi yang dibutuhkan investor. Hasil ini mendukung penelitian yang telah dilakukan sebelumnya oleh Sejati dan Prastiwi (2015).

\begin{tabular}{|c|c|c|c|c|c|}
\hline & Original Sample (0) & Sample Mean (M) & Standard Deviation (STDEV) & T Statistics $(|0 / S T D E V|)$ & P Values \\
\hline Kinerja Keuangan -> Nilai Perusahaan & 0.380 & 0.395 & 0.185 & 2.056 & 0.040 \\
\hline Pengungkapan Ekonomi $\rightarrow>$ Kinerja Keuangan & 0.561 & 0.563 & 0.150 & 3.743 & 0.000 \\
\hline Pengungkapan Ekonomi -> Nilai Perusahaan & -0.276 & -0.277 & 0.146 & 1.891 & 0.059 \\
\hline Pengungkapan Lingkungan -> Kinerja Keuangan & 0.038 & 0.044 & 0.086 & 0.437 & 0.662 \\
\hline Pengungkapan Lingkungan $->$ Nilai Perusahaan & 0.059 & 0.048 & 0.100 & 0.594 & 0.553 \\
\hline Pengungkapan Sosial -> Kinerja Keuangan & 0.352 & 0.347 & 0.148 & 2.389 & 0.017 \\
\hline Pengungkapan Sosial -> Nilai Perusahaan & 0.775 & 0.764 & 0.177 & 4.374 & 0.000 \\
\hline
\end{tabular}

\section{Gambar 2. Hasil Penelitian}

\section{$H_{1 b:}$ Pengungkapan Lingkungan Berpengaruh Terhadap Nilai Perusahaan}

Path coefficient menunjukkan bahwa hubungan antara pengungkapan lingkungan dengan nilai perusahaan tidak berpengaruh dengan nilai $T$-Statistic sebesar $0.594<T$-Table sebesar 2.056 dan $P$-Value sebesar $0.553>0,05(\alpha=$ $5 \%$ ). Nilai dari original sampel 0,059. Hipotesis H1b dalam penelitian ini ditolak. Pengungkapan lingkungan yang dilaporkan perusahaan belum menjadi daya tarik yang kuat oleh investor dalam pengambilan keputusan. Investor cenderung memiliki kesadaran yang rendah terhadap lingkungan. Selain itu masyarakat lebih membutuhkan bantuan sosial dari perusahaan terkait dengan pendapatan mereka yang masih rendah. Tanggung jawab sosial lebih menjadi perhatian di kalangan masyarakat daripada tanggung jawab akan lingkungan. 
Hasil ini mendukung penelitian yang telah dilakukan sebelumnya oleh Sejati dan Prastiwi (2015). Hasil ini tidak konsisten dengan penelitian yang dilakukan oleh Plumlee, dkk (2015)

\section{H1c: Pengungkapan Sosial Berpengaruh Terhadap Nilai Perusahaan}

Path coefficient menunjukkan bahwa hubungan antara pengungkapan sosial dengan nilai perusahaan berpengaruh dengan nilai $T$-Statistic sebesar $4.374>T$ Table sebesar 2.056 dan P-Value sebesar $0.00<0,05(\alpha=5 \%)$. Nilai dari original sampel 0,775. Hipotesis H1c dalam penelitian ini diterima. Sesuai dengan legitimacy theory yang memfokuskan pada interaksi antara perusahaan dengan masyarakat, ketika perusahaan beroperasi ditengah lingkungan masyarakat dan berusaha meyakinkan bahwa perilaku mereka sesuai dengan batas dan norma masyarakat. Pengungkapan sosial yang dilakukan oleh perusahaan dapat meningkatkan image perusahaan, meningkatkan akuntabilitas perusahaan, serta memberikan informasi kepada investor yang berpengaruh terhadap nilai perusahaan. Hasil ini tidak konsisten dengan penelitian yang telah dilakukan sebelumnya oleh Sejati dan Prastiwi (2015).

\section{$H_{2 a}$ : Pengungkapan Ekonomi Berpengaruh Terhadap Kinerja Keuangan}

Path coefficient menunjukkan bahwa hubungan antara pengungkapan ekonomi dengan kinerja keuangan berpengaruh dengan nilai T-Statistic sebesar 3.743>T-Table sebesar 2.056 dan P-Value sebesar $0.000<0,05(\alpha=5 \%)$. Nilai dari original sampel 0,561. Hipotesis $\mathrm{H} 2 \mathrm{a}$ dalam penelitian ini diterima. Pengungkapan ekonomi dapat meningkatkan transparansi perusahaan yang berdampak pada peningkatan kepercayaan investor serta meningkatkan kinerja keuangan. Dengan adanya kepercayaan dari investor, maka investor tidak akan ragu untuk melakukan penginvestasian pada perusahaan tersebut. Penginvestian menyebabkan jumlah pendanaan pada perusahaan meningkat. Pendanaan tersebut digunakan perusahaan untuk meningkatkan operasional perusahaan yang dapat meningkatkan kinerja keuangan perusahaan. Hasil ini mendukung penelitian yang telah dilakukan sebelumnya oleh Puspitandari dan Septiani (2017). Hasil ini tidak sejalan dengan penelitian yang dilakukan oleh Tarigan dan Semuel (2014), Hutagalung dan Harahap (2016), Karyawati, dkk (2017).

\section{$H_{2 b:}$ Pengungkapan Lingkungan Berpengaruh Terhadap Kinerja Keuangan}

Path coefficient menunjukkan bahwa hubungan antara pengungkapan lingkungan dengan kinerja keuangan tidak berpengaruh dengan nilai T-Statistic sebesar $0.437<$ T-Table sebesar 2.056 dan $P$-Value sebesar $0.662>0,05(\alpha=$ 
5\%). Nilai dari original sampel 0,038. Hipotesis $\mathrm{H} 2 \mathrm{~b}$ dalam penelitian ini ditolak. Hal tersebut dapat dikarenakan pengungkapan lingkungan yang dilakukan oleh perusahaan menjadi biaya tambahan untuk perusahaan. Biaya tersebut dapat berdampak pada pengurangan aset perusahaan. Selain itu investor cenderung memiliki kesadaran yang rendah terhadap lingkungan, serta kondisi lingkungan di Indonesia kurang menjadi perhatian dimata publik. Hasil ini mendukung penelitian yang telah dilakukan sebelumnya oleh Hutagalung dan Harahap (2016). Hasil ini bertentangan dengan penelitian yang dilakukan oleh Nurleli dan Faisal (2013).

\section{$H_{2 c:}$ Pengungkapan Sosial Berpengaruh Terhadap Kinerja Keuangan}

Path coefficient menunjukkan bahwa hubungan antara pengungkapan sosial dengan kinerja keuangan berpengaruh dengan nilai T-Statistic sebesar 2.389>T-Table sebesar 2.056 dan P-Value sebesar $0.017<0,05(\alpha=5 \%)$. Nilai dari original sampel 0,352 . Hipotesis $\mathrm{H} 2 \mathrm{c}$ dalam penelitian ini diterima. Pengungkapan sosial perusahaan mampu untuk meyakinkan para stakeholder. Pengungkapan sosial yang dilakukan perusahaan seperti pemberian beasiswa terhadap pelajar yang berprestasi dan kurang mampu, perbaikan sarana dan prasarana umum, bantuan pembuatan sumur, merekrut masyarakat disekitar perusahaan beroperasi, dan lain sebagainya dapat mengakibatkan citra perusahaan meningkat dari pandangan stakeholder. Stakeholder beranggapan bahwa perusahaan memiliki perhatian dan kepedulian terhadap sosial tempat perusahaan beroperasi. Hal tersebut berdampak pada meningkatnya penginvestasian yang dilakukan oleh investor pada perusahaan. Investasi yang meningkat dapat meningkatkan kinerja keuangan perusahaan. Hasil ini mendukung penelitian yang telah dilakukan sebelumnya oleh Tarigan dan Semuel (2014), Hutagalung dan Harahap (2016), Puspitandari dan Septiani (2017).

\section{H3: Kinerja Keuangan Berpengaruh Terhadap Nilai Perusahaan}

Path coefficient menunjukkan bahwa hubungan antara kinerja keuangan berpengaruh dengan nilai perusahaan dengan nilai T-Statistic sebesar $2.056=$ T-Table sebesar 2.056 dan P-Value sebesar $0.040<0,05(\alpha=5 \%)$. Nilai dari original sampel 0,380. Hipotesis H3 dalam penelitian ini diterima. Kinerja keuangan yang diukur menggunakan profitabilitas menunjukkan kemampuan perusahaan dalam menghasilkan keuntungan dari kekayaan yang dimilikinya. ROA menggambarkan kinerja keuangan perusahaan dalam menghasilkan laba bersih dan aktiva yang digunakan untuk operasional perusahaan. ROA yang semakin tinggi menunjukkan bahwa kinerja keuangan perusahaan semakin baik, sehingga meningkatkan image perusahaan yang pada akhirnya meningkatkan nilai perusahaan dalam pandangan stakeholder. Laba yang terus 
meningkat memberikan gambaran bahwa perusahaan memiliki kinerja yang baik dan mampu memberikan pengembalian atas investasi yang dilakukan investor. Semakin banyak investor yang membeli saham perusahaan, maka harga saham akan meningkat yang kemudian nilai perusahaan akan ikut meningkat. Hasil ini mendukung penelitian yang dilakukan oleh Ulum (2015), Sabrin, dkk (2016), Cheryta, dkk (2017), Tauke, dkk (2017). Hasil penelitian ini tidak konsisten dengan penelitian yang dilakukan Tjandrakirana dan Monika (2014).

\section{H4a: Pengungkapan Ekonomi Berpengaruh Terhadap Nilai Perusahaan Melalui Kinerja Keuangan}

Dari tabel path coefficient, Gambar 2, diketahui bahwa dua jalur signifikan (jalur pengungkapan ekonomi $\rightarrow$ kinerja keuangan, dan kinerja keuangan $\rightarrow$ nilai perusahaan). Dengan demikian dapat disimpulkan bahwa ada pengaruh tidak langsung pada pengungkapan ekonomi terhadap nilai perusahaan dengan kinerja keuangan sebagai variabel antara. Hasil tersebut diperkuat dengan nilai sobel test sebesar 10.49>T-Table sebesar 2.056. Dengan demikian Hipotesis H4a dalam penelitian ini diterima.

Pengungkapan ekonomi yang dilakukan perusahaan dapat meyakinkan stakeholder dan pihak-pihak lainnya, karena perusahaan dianggap mampu untuk menjelaskan dan mempertanggungjawabkan tuntutan stakeholder terkait kinerja ekonomi perusahan. Investor cenderung untuk melakukan penginvestasian pada perusahaan yang transparan terhadap informasi yang dikeluarkan oleh perusahaan. Semakin banyak investor yang melakukan penginvestasian, maka dapat menyebabkan meningkatnya pendanaan perusahaan. Pendanaan perusahaan dapat digunakan untuk operasional perusahaan serta dapat meningkatkan kinerja keuangan perusahaan. Kinerja keuangan yang meningkat dapat meningkatkan pula nilai suatu perusahaan. Kinerja keuangan yang baik dapat meyakinkan investor bahwa perusahaan mampu memberikan pengembalian atas investasi yang ditanamkan investor. Semakin banyak investor yang membeli saham, maka harga saham perusahaan juga terus meningkat. Harga saham yang terus meningkat berdampak pada meningkatnya nilai perusahaan.

\section{H4b: Pengungkapan Lingkungan Berpengaruh Terhadap Nilai Perusahaan Melalui Kinerja Keuangan}

Dari tabel path coefficient, Gambar 2, diketahui bahwa terdapat jalur tidak signifikan (jalur pengungkapan lingkungan $\rightarrow$ kinerja keuangan), serta terdapat jalur yang signifikan (jalur kinerja keuangan $\rightarrow$ nilai perusahaan). Dengan demikian dapat disimpulkan bahwa tidak ada pengaruh tidak langsung pada 
pengungkapan lingkungan terhadap nilai perusahaan dengan kinerja keuangan sebagai variabel antara. Hasil tersebut diperkuat dengan nilai dari sobel test sebesar 1.88<T-Table sebesar 2.056. Dengan demikian hipotesis H4b dalam penelitian ini ditolak. Hasil tersebut menunjukkan bahwa ditinjau dari kesadaran investor terhadap lingkungan yang masih rendah serta kondisi lingkungan di Indonesia kurang menjadi perhatian. Oleh karenanya kondisi tersebut dapat mempengaruhi mengapa kinerja keuangan gagal memediasi hubungan antara pengungkapan lingkungan dengan nilai perusahaan. Pengungkapan lingkungan juga dianggap perusahaan sebagai biaya tambahan yang dapat mengurangi aset dan laba perusahaan. Hal tersebut memberikan penjelasan bahwa pengungkapan lingkungan tidak berpengaruh terhadap kinerja keuangan perusahaan.

\section{H4c: Pengungkapan Sosial Berpengaruh Terhadap Nilai Perusahaan Melalui Kinerja Keuangan}

Dari tabel path coefficient, Gambar 2, diketahui bahwa dua jalur signifikan (jalur pengungkapan sosial $\rightarrow$ kinerja keuangan, dan kinerja keuangan $\rightarrow$ nilai perusahaan). Dengan demikian dapat disimpulkan bahwa ada pengaruh tidak langsung pada pengungkapan sosial terhadap nilai perusahaan dengan kinerja keuangan sebagai variabel antara. Hasil tersebut diperkuat dengan nilai dari sobel test sebesar 8.60 >T-Table sebesar 2.056. Dengan demikian Hipotesis H4c dalam penelitian ini diterima. Pengungkapan sosial yang dilakukan perusahaan mampu untuk meyakinkan para stakeholder dan pihak-pihak lainnya.

Pengungkapan sosial yang dilakukan perusahaan seperti pemberian beasiswa terhadap pelajar yang berprestasi dan kurang mampu, perbaikan sarana dan prasarana umum, bantuan pembuatan sumur, perekrutan karyawan dari masyarakat disekitar perusahaan beroperasi, dan lain sebagainya dapat mengakibatkan citra perusahaan meningkat dari pandangan stakeholder. Stakeholder beranggapan bahwa perusahaan memiliki perhatian dan kepedulian terhadap sosial tempat perusahaan beroperasi. Hal tersebut berdampak pada meningkatnya penginvestasian yang dilakukan oleh investor pada perusahaan. Investasi yang meningkat dapat meningkatkan pula kinerja keuangan perusahaan. Kinerja keuangan yang meningkat dapat meningkatkan pula nilai suatu perusahaan. Kinerja keuangan yang baik dapat meyakinkan investor bahwa perusahaan mampu memberikan pengembalian atas investasi yang ditanamkan investor. Semakin banyak investor yang membeli saham, maka harga saham perusahaan juga terus meningkat. Harga saham yang terus meningkat berdampak pada meningkatnya nilai perusahaan.

\section{Simpulan}


Penelitian ini bertujuan untuk mengkaji pengaruh langsung dan tidak langsung pengungkapan ekononi, sosial dan lingkungan terhadap nilai perusahaan. Penelitian ini menghasilkan sepuluh temuan penting yaitu: (1) Pengungkapan ekonomi tidak berpengaruh terhadap nilai perusahaan, (2) Pengungkapan lingkungan tidak berpengaruh terhadap nilai perusahaan, (3) Pengungkapan sosial berpengaruh terhadap nilai perusahaan, (4) Pengungkapan ekonomi berpengaruh terhadap kinerja keuangan, (5) Pengungkapan lingkungan tidak berpengaruh terhadap kinerja keuangan, (6) Pengungkapan sosial berpengaruh terhadap kinerja keuangan, (7) Kinerja keuangan berpengaruh terhadap nilai perusahaan, (8) Pengungkapan ekonomi berpengaruh tidak langsung terhadap nilai perusahaan melalui kinerja keuangan, (9) Pengungkapan lingkungan tidak berpengaruh terhadap nilai perusahaan melalui kinerja keuangan, (10) Pengungkapan sosial berpengaruh tidak langsung terhadap nilai perusahaan melalui kinerja keuangan.

Penelitian memiliki beberapa keterbatasan. Pertama, penelitian ini berfokus pada satu industri yaitu sektor perbankan, sehingga cakupan analisis telah terbatas. Oleh karenanya, penelitian selanjutnya dapat mengembangkan sampel pada perusahaan sektor yang lain, sehingga hasilnya dapat lebih di generalisasi. Kedua, periode pengamatan penelitian ini selama empat tahun. Penelitian selanjutnya dapat menambah periode pengamatan, sehingga penelitian tentang pengaruh pengungkapan ekonomi, lingkungan dan sosial dapat lebih akurat. Ketiga, penelitian ini menggunakan ROA sebagai ukuran kinerja keuangan. Penelitian selanjutnya dapat menggunakan ukuran yang berbeda seperti Return On Equity (ROE), Basic Earning Power. Demikian juga untuk pengukuran nilai perusahaan, penelitian ini menggunakan rasio Tobin's Q. Selain itu penelitian di masa mendatang dapat menggunakan Price to Earning Ratio atau Price to Book Value sebagai ukuran nilai perusahaan.

\section{Daftar Pustaka}

Cheryta, A. M., Moeljadi, \& Indrawati, N. K. (2017). The Effect of Leverage , Profitability , Information Asymmetry, Firm Size on Cash Holding and Firm Value of Manufacturing Firms Listed at Indonesian Stock Exchange. International Journal of Research in Business Studies and Management, 4(4), 21-31. https://doi.org/10.22259/ijrbsm.0404004

Connelly, B. L., Certo, S. T., Ireland, R. D., \& Reutzel, C. R. (2011). Signaling theory: A review and assessment. Journal of Management, 37(1), 39-67. https://doi.org/10.1177/0149206310388419

Ghozali, I. (2008). Model Persamaan Struktural. Semarang: Badan Penerbit Universitas Diponegoro.

GRI. (2006). G4 Pedoman Pelaporan Keberlanjutan. 
Gultom, R., Agustina, \& Wijaya, S. W. (2013). Analisis Faktor Faktor yang Mempengaruhi Nilai Perusahaan Farmasi di Bursa Efek Indonesia periode 2008-2011. Jurnal Wira Ekonomi Mikroskil, 3(1), 51-60.

Gunawan, Y., \& Mayangsari, S. (2015). Pengaruh Sustainability Reporting terhadap Nilai Perusahaan dengan Investment Opportunity Set sebagai Variabel Moderating. E-Journal Akuntansi Trisakti, 2(1 February), 1-12.

Hutagalung, A., \& Harahap, K. (2016). Pengaruh Pengungkapan Sustainability Report Terhadap Profitabilitas Perusahaan Manufaktur Yang Terdaftar Di Bursa Efek Indonesia Periode 2009-2012. Jurnal Akuntansi, Keuangan \& Perpajakan Indonesia, 03(1), 1-14.

Karyawati, N. A. N., Yuniarta, G. A., \& Sujana, E. (2017). Pengaruh Tingkat Pengungkapan Laporan Keberlanjutan terhadap Kinerja Keuangan Perusahaan. E-Journal Akuntansi Universitas Pendidikan Ganesha, 7(1).

Kusuma, A. W., \& Priantinah, D. (2018). Pengaruh Pengungkapan Sustainability Report Dan Ukuran Sebagai Variabel Pemoderasi Pada Perusahaan Yang Bergabung Di Issi Dan Konvensional Periode 2014-2016 the Influence of Sustainability Report Disclosure and Company 'S Size on Company' S Value With P. Jurnal Nominal, VII(2), 91-105.

Muallifin, O. R., \& Priyadi, M. P. (2016). Dampak Pengungkapan Sustainability Report Terhadap Kinerja Keuangan Dan Kinerja Pasar. Jurnal Ilmu Dan Riset Akuntansi, 5(5).

Plumlee, M., Brown, D., Hayes, R. M., \& Marshall, R. S. (2015). Voluntary environmental disclosure quality and firm value: Further evidence. Journal of Accounting and Public Policy, 34(4), 336-361. https://doi.org/10.1016/j.jaccpubpol.2015.04.004

Puspitandari, J., \& Septiani, A. (2017). Pengaruh Sustainability Report Disclosure Terhadap Kinerja Perbankan. Diponegoro Journal of Accounting, 6(3), 159170.

Rahayu, M., \& Sari, B. (2018). Faktor-Faktor Yang Mempengaruhi Nilai Perusahaan. IKRAITH-HUMANIORA, $12(2), \quad 69-76$. https://doi.org/10.31603/bisnisekonomi.v16i1.2127

Sabrin, Sarita, B., Takdir, D., \& Sujono. (2016). Actomyosin relationships with surface features in fibroblast adhesion. Experimental Cell Research, 5(10), 2319 1805. https://doi.org/10.1016/0014-4827(80)90264-5

Safitri, D. A. (2015). Sustainability Report Terhadap Kinerja Keuangan Dan Pasar. Jurnal Ilmu \& Riset Akuntansi, 4(4), 1-15.

Sejati, B. P., \& Prastiwi, A. (2015). Pengaruh Pengungkapan Sustainability Report Terhadap Kinerja Dan Nilai Perusahaan. Diponegoro Journalof Accounting, 4(1), 195-206.

Subandi, \& Ghozali, I. (2013). Determinan Efisiensi Dan Dampaknya Terhadap Kinerja Profitabilitas Industri Perbankan Di Indonesia. Jurnal Keuangan Dan Perbankan, 17(1), 123-135.

Sulastri, H. (2018). Analisis Kinerja Keuangan Perusahaan Dengan Menggunakan Rasio Likuiditas, Aktivitas, Solvabilitas Dan Profitabilitas (Studi Kasus Pada PT. 
Smart Tbk). EJournal Administrasi Bisnis, 6(1), 257-267. https://doi.org/10.1111/j.1464-410X.2012.10971.x

Tarigan, J., \& Semuel, H. (2014). Pengungkapan Sustainability Report dan Kinerja Keuangan. Jurnal Akuntansi Dan Keuangan, 16(2), 88-101. https://doi.org/10.9744/jak.16.2.88-101

Tauke, Y. P., Murni, S., \& Tulung, J. E. (2017). Pengaruh Kinerja Keuangan Terhadap Nilai Perusahaan Real Estate and Property Yang Terdaftar Di Bursa Efek Indonesia Tahun the Effect of Financial Performance on the Value of Real Estate and Propertycompanies Listed on the Indonesian Stock Exchange in 2012. Jurnal EMBA, 5(2), 919-927.

Ulum, A. . (2015). The Influence Of Profitability And Capital Structure On Firm Value. Media Mahardhika, 14(1), 79-97. 